\title{
RAISING EFL STUDENTS' AWARENESS OF PRAGMATIC CONVENTIONS IN FORMING INTERCULTURAL COMPETENCE
}

\author{
İsmail Erton"
}

\begin{abstract}
For almost half a century, teaching and learning a language and even the linguistic studies related to them were elaborated in a structural framework. Both the focus on teaching/learning methods and the linguistic corpus offered within such curricula were far from that of developing EFL students' cross-cultural interactions. This paper suggests that the implementation of a pedagogy of pragmatics in foreign language instruction facilitates the development of intercultural competence and activates the cross-cultural schemata of the learners. The pragmatically-oriented social behavior which embodies political, sociocultural and economic conventions can be integrated into the EFL curriculum via translation, literary studies and digital multimedia technology. It is shown that, by forming intercultural competence, language learners can feel more secure in communicative practices within various sociocultural contexts and, thus, the significance of teaching and learning pragmatic knowledge to master the skills in a foreign language should be emphasized as not only a fundamental principle in linguistic practices, but also as an ultimate goal in EFL instruction.
\end{abstract}

Key words: Linguistics, pragmatics, pragmatic competence, intercultural competence, foreign language teaching, foreign language learning, curriculum, communication, schemata

\section{Background to Pragmatic Studies in Linguistics}

The frame of linguistic studies shifted from a structural approach to communicative practices after Chomsky's book Aspects of the Theory of Syntax published in 1965. In his book, he concentrated on the notion of linguistic competence and defined it as the complete knowledge of a language possessed by the ideal speaker-listener in a homogenous speech community. Chomsky put forward the concept of generative grammar as the theory of linguistic competence and performance. Wales and Marshall criticized Chomsky's approach to competence and claimed that "It is also a theory of limitations of the mechanisms, which enable us to express our own linguistic competence" (1966: 30). The center of attention in these debates was mainly the coverage

\footnotetext{
* Assist. Prof. PhD at Atılim University, Department of Translation and Interpretation, Ankara, Turkey, e-mail: ismail.erton@atilim.edu.tr.
} 
zone of linguistic competence, such as whether or not it should also deal with language production at the verbal state. Fodor and Garrett claimed that in a model of linguistic performance, the role of psycholinguistics should not be underestimated, saying that "both linguistic and psychological models are the models of competence" (1966: 138).

The discussions about the mental state of the language user and her capacity to produce both syntactically and semantically appropriate utterances led the direction of linguistics to the functional interpretation of language rather than framing it with structural conventions. As Choraih et al. state, "This branch investigates the psycholinguistic aspects of the process of L2 acquisition, in which the study of linguistics had little to do with language teaching, the focus being primarily on the formal linguistic properties of the learner's interlanguage" (2016: 184). One could argue that, perhaps, what made language teaching methods unsuccessful and inefficient in those days was the approach to consider psychological and structural studies in isolation from their practices in the socio-cultural contexts, where language is communicated authentically and naturally. Choraih et al. adds that, "this line of research had become less tenable with the increasing attention to the role of sociocultural and sociolinguistic factors that affect and shape the process of L2 development" (2016: 184).

Hymes (1972) and Gumperz and Dell (1989) concentrated on the communicative sociocultural aspects of human interaction and claimed that the communicative value of language needs to be considered not only with reference to its structural and psychological aspects, but also within the limits of its social use, in which communication essentially acts through various discourses. Such discourses offer contexts where language becomes a product of a strategic competence, embodying unlimited strategies to be deployed in verbal and non-verbal communication alike. Canale and Swain (1980) and Canale (1983) drew the attention of linguistics to personal skills and capabilities which would operate skillfully and strategically in sociocultural contexts. Meanwhile, Widdowson (1983) redefined the term 'schemata' from an applied linguistic point of view. For him, there are two levels of language: systemic and schematic, the latter of which encompasses a series of cognitive processes that operate in a systematic manner. The systemic level itself, which includes the structural aspects of language (phonetic, phonological, morphological, etc.), is in a continuous interaction with the schematic level that represents the background knowledge of the language user. In addition, Bachman's notion of communicative competence introduced psycho-physiological mechanisms, helping linguists to better understand the neuro-psychological process of language production (1990: 107-8). In this respect, Dijk's definition of communicative competence is thought to represent a model that sums up the findings of previous studies: 
... study of pragmatics requires an analysis of its foundations. This basis of pragmatics theories is on the one hand conceptual e.g. in the analysis of action and interaction, and on the other hand empirical, viz. in the investigation of psychological and social properties of language processing in communicative interaction (Dijk 1977: 121).

Despite all of the afore-mentioned views, the studies that have been covered so far lacked in explaining how language acts even in unforeseen discourses. Oller, in this respect, defined pragmatic competence as, "the relationship between linguistic contexts and extra-linguistic contexts. It embraces the traditional subject matter of psycholinguistics and also that of sociolinguistics" (1970: 19). Crystal defines pragmatics as, "the study of language from the point of view of users, especially of the choices they make, the constraints they encounter in using language in social interaction and the effects of their use of language has on other participants in the act of communication" (2008: 379). Crystal studied pragmatics as a tool that engenders social interaction, in which the addresser and the addressee develop, produce and comprehend acts in social discourses. Leech (1983) investigated pragmatics in two sub-fields as: 'pragmalinguistics' and 'sociopragmatics'. Leech's fundamental consideration was on how social conventions influenced language production and were used in social contexts. In this respect, and concerning the definition of pragmatics, Brown states that it is "the intersection of pragmatics and linguistic forms" (2007: 223).

\section{Forming Intercultural Competence in the EFL Classroom}

Effective production and proficient use of language can only be achieved if grammatical and lexical knowledge is not offered in isolation from its social usage. As Krisnawati states, "language teaching for many years had devoted to the grammar accuracy hence communicative function of language seemed to be put aside" (2011: 105). Isolating language use from structure and considering the teaching of the functional properties of language as a separate act caused serious communication problems in contexts in which language is used either in artificial (classroom, meetings, conferences, etc.) or in authentic (native speaker's environment) discourses. As Li et.al. cited in Nelson, Carson, Batal $\&$ Bakary (2002) state "Compared with grammatical mistakes pragmatic errors may cause more serious problems in communication because they are typically interpreted by native speakers as arrogance, impatience and rudeness, and thus they are less likely to be forgiven by native speakers" (2015: 41).

The linguistic input (phonetics, phonology, morphology, syntax, semantics) offered to EFL students in the language classroom is far away from meeting the needs of both language learners and teachers alike. The former might become aware of almost all grammatical patterns in the target language, but unless such 
conventions are practiced and inspired by their authentic socio-cultural usage, communication breakdown or failure seems to be the sole probable outcome.

A variety of studies have been attempted to investigate how beneficial it is to raise the pragmatic awareness of the EFL learners. Mwinyelle (2005) conducted a case study about the way intermediate-level learners of Spanish learn how to 'give advice' in the target language. Explicit instruction, video sessions, and meta-pragmatic discussions were offered to one group of learners, and another two groups were offered conventional practices. The results showed that the students in the first group performed better in providing advice in Spanish in varying contexts and even in unforeseen discourses. Likewise, Fukaya and Martyn (2001) carried out a study on the influence of instruction on the learners' ability to make requests, with the results that implicit instruction plays a positive role in learner's developing strategies as they make requests. In this respect, another debate was on whether implicit or explicit instruction is more influential in forming pragmatic competence for sociocultural practices.

So far, research on testing the effectiveness of implicit or explicit instruction in raising pragmatic consciousness has not presented any clear outcomes, and it is hard to claim with certainty that there is a statistically significant relationship between implicit/explicit instruction and the development of pragmatic competence. Kasper and Rose (2002), in their book 'Pragmatic Development in a Second Language' studied 'motivation as a contributory factor in L2 instruction for more pragmatic awareness and development. For them, motivation helps language learners to become aware of their pragmatic mistakes and act more willingly to eliminate such deficiencies in socio-cultural contexts. Abolfathiasl $\&$ Abdullah discusses the significance of achieving pragmatic competence depending on the study of Bardovi-Harlig and Griffin (2005). He states that their study:

"implies that even though learners displayed pragmatic awareness to some extents and were able to repair some infelicities, they did not possess the tools needed to make more target-like forms in the repairs. The implication of this is that mere pragmatic awareness may not be enough for producing target-like forms and that language learners should be provided with metapragmatic awareness, which is a higher level of consciousness about various structures and strategies and their relationships with contextual factors in speech act performance ... " (2015: 334).

Mey, in his book 'Pragmatics' defined linguistic behavior as a social behavior. For him, a communicative act which takes place in a communicative environment - that is, the nature of a linguistic action - is determined by political, economic, and social rules, regulations and perspectives (1993: 186-7). Taking the 
previously stated studies into account, it is possible to say that even increasing the EFL learners' awareness of sociocultural conventions to frame a functional pragmatic competence which would act independent of L1 linguistic traditions might not be enough to perform a successful communicative act. To do this, meta-pragmatic instruction, which embodies the skillful and strategic use of socio-cultural conventions, should become a significant aspect of linguistic practices in the EFL classroom. However, to achieve this goal is not as easy as it seems. Kasper, in her article 'Can pragmatic competence be taught', lists a series of research works demonstrating the activities and instruments that teachers can use in order to develop their students' pragmatic competence (1997: 13):

\begin{tabular}{|c|c|c|c|c|c|c|}
\hline STUDY & $\begin{array}{c}\text { TEACH- } \\
\text { ING GOAL }\end{array}$ & $\begin{array}{l}\text { PROFI- } \\
\text { CIEN- } \\
\text { CY }\end{array}$ & $\begin{array}{l}\text { LAN- } \\
\text { GUAGES }\end{array}$ & $\begin{array}{l}\text { RESEARCH } \\
\text { GOAL }\end{array}$ & DESIGN & $\begin{array}{c}\text { ASSESS- } \\
\text { MENT/ } \\
\text { PROCEDURE/ } \\
\text { INSTRU- } \\
\text { MENT }\end{array}$ \\
\hline $\begin{array}{l}\text { House \& } \\
\text { Kasper } 1981\end{array}$ & $\begin{array}{l}\text { discourse } \\
\text { markers \& } \\
\text { strategies }\end{array}$ & $\begin{array}{l}\text { ad- } \\
\text { vanced }\end{array}$ & $\begin{array}{l}\text { L1 German } \\
\text { FL English }\end{array}$ & $\begin{array}{l}\text { explicit vs } \\
\text { implicit }\end{array}$ & $\begin{array}{l}\text { pre-test/ } \\
\text { post-test } \\
\text { control } \\
\text { group L2 } \\
\text { baseline }\end{array}$ & roleplay \\
\hline $\begin{array}{l}\text { Wildner- } \\
\text { Bassett 1984, } \\
1986\end{array}$ & $\begin{array}{l}\text { pragmatic } \\
\text { routines }\end{array}$ & $\begin{array}{l}\text { inter- } \\
\text { mediate }\end{array}$ & $\begin{array}{l}\text { L1 German } \\
\text { FL English }\end{array}$ & $\begin{array}{l}\text { eclectic vs } \\
\text { suggesto- } \\
\text { pedia }\end{array}$ & $\begin{array}{l}\text { pre-test/ } \\
\text { post-test } \\
\text { control } \\
\text { group }\end{array}$ & roleplay \\
\hline Billmyer 1990 & compliment & $\begin{array}{l}\text { high in- } \\
\text { terme- } \\
\text { diate }\end{array}$ & $\begin{array}{l}\text { L1 Japanese } \\
\text { SL English }\end{array}$ & $+/$-instruction & $\begin{array}{l}\text { pre-test/ } \\
\text { post-test } \\
\text { control } \\
\text { group L2 } \\
\text { baseline }\end{array}$ & $\begin{array}{l}\text { elicited conver- } \\
\text { sation }\end{array}$ \\
\hline $\begin{array}{l}\text { Olshtain \& } \\
\text { Cohen } 1990\end{array}$ & apology & $\begin{array}{l}\text { ad- } \\
\text { vanced }\end{array}$ & $\begin{array}{l}\text { L1 Hebrew } \\
\text { FL English }\end{array}$ & teachability & $\begin{array}{l}\text { pre-test/ } \\
\text { post-test } \\
\text { L2 base- } \\
\text { line }\end{array}$ & $\begin{array}{l}\text { discourse } \\
\text { completion } \\
\text { question. }\end{array}$ \\
\hline $\begin{array}{l}\text { Wildner- } \\
\text { Bassett } 1994\end{array}$ & $\begin{array}{l}\text { pragmatic } \\
\text { routines \& } \\
\text { strategies }\end{array}$ & $\begin{array}{l}\text { begin- } \\
\text { ning }\end{array}$ & $\begin{array}{l}\text { L1 English } \\
\text { SL German }\end{array}$ & $\begin{array}{l}\text { teachability } \\
\text { to beginning } \\
\text { FL students }\end{array}$ & $\begin{array}{l}\text { pre-test/ } \\
\text { post-test }\end{array}$ & $\begin{array}{l}\text { question-naires } \\
\text { roleplay }\end{array}$ \\
\hline Bouton 1994 & implicature & $\begin{array}{l}\text { ad- } \\
\text { vanced }\end{array}$ & $\begin{array}{l}\text { L1 mixed } \\
\text { SL English }\end{array}$ & $+/$-instruction & $\begin{array}{l}\text { pre-test/ } \\
\text { post-test } \\
\text { control } \\
\text { group }\end{array}$ & $\begin{array}{l}\text { multiple choice } \\
\text { question }\end{array}$ \\
\hline Kubota 1995 & implicature & $\begin{array}{l}\text { inter- } \\
\text { mediate }\end{array}$ & $\begin{array}{l}\text { L1 Japanese } \\
\text { FL English }\end{array}$ & $\begin{array}{l}\text { deductive vs } \\
\text { inductive vs } \\
\text { zero }\end{array}$ & $\begin{array}{l}\text { pre-test/ } \\
\text { post-test/ } \\
\text { delayed } \\
\text { post-test } \\
\text { control } \\
\text { group }\end{array}$ & $\begin{array}{l}\text { multiple choice } \\
\& \text { sentence } \\
\text { combining } \\
\text { question }\end{array}$ \\
\hline
\end{tabular}




\begin{tabular}{|l|l|l|l|l|l|l|}
\hline STUDY & $\begin{array}{c}\text { TEACH- } \\
\text { ING GOAL }\end{array}$ & $\begin{array}{c}\text { PROFI- } \\
\text { CIEN- } \\
\text { CY }\end{array}$ & $\begin{array}{c}\text { LAN- } \\
\text { GUAGES }\end{array}$ & $\begin{array}{l}\text { RESEARCH } \\
\text { GOAL }\end{array}$ & DESIGN & $\begin{array}{c}\text { ASSESS- } \\
\text { MENT/ } \\
\text { PROCEDURE/ } \\
\text { INSTRU- } \\
\text { MENT }\end{array}$ \\
\hline House 1996 & $\begin{array}{l}\text { pragmatic } \\
\text { fluency }\end{array}$ & $\begin{array}{l}\text { ad- } \\
\text { vanced }\end{array}$ & $\begin{array}{l}\text { L1 German } \\
\text { FL English }\end{array}$ & $\begin{array}{l}\text { explicit vs } \\
\text { implicit }\end{array}$ & $\begin{array}{l}\text { pre-test/ } \\
\text { post-test } \\
\text { control } \\
\text { group }\end{array}$ & roleplay \\
\hline Morrow 1996 & $\begin{array}{l}\text { complaint \& } \\
\text { refusal }\end{array}$ & $\begin{array}{l}\text { inter- } \\
\text { mediate }\end{array}$ & $\begin{array}{l}\text { L1 mixed } \\
\text { SL English }\end{array}$ & $\begin{array}{l}\text { teachability/ } \\
\text { explicit }\end{array}$ & $\begin{array}{l}\text { post-test/ } \\
\text { delayed } \\
\text { post-test } \\
\text { L2 base- } \\
\text { line }\end{array}$ & $\begin{array}{l}\text { releplay holis- } \\
\text { tic ratings }\end{array}$ \\
\hline $\begin{array}{l}\text { Tateyama et } \\
\text { al. 1997 }\end{array}$ & $\begin{array}{l}\text { pragmatic } \\
\text { routines }\end{array}$ & $\begin{array}{l}\text { begin- } \\
\text { ning }\end{array}$ & $\begin{array}{l}\text { L1 English } \\
\text { FL Japanese }\end{array}$ & $\begin{array}{l}\text { explicit vs } \\
\text { implicit }\end{array}$ & $\begin{array}{l}\text { pre-test/ } \\
\text { post-test } \\
\text { control } \\
\text { group }\end{array}$ & multi-method \\
\hline
\end{tabular}

Table 1: Studies examining the effect of pragmatic instruction

When the above studies that examine the effects of pragmatic instruction are taken into account, one can easily see that despite limitations in terms of the students' proficiency levels, the research is established on a large range of pragmatic features, through which the data is tested and evaluated by different assessment procedures and instruments. In addition, perhaps one of the significant points to focus on in the table is that the research has been carried out not only for English language, but also for Japanese and German. In this, way, the above research presents a wider perspective in which the influence of pragmatic instruction takes place. Along the same line, Kasper summarizes the studies in the table by saying, ". . . the research supports the view that pragmatic ability can indeed be systematically developed through planful classroom activities" (1997: 8).

What's more, the contribution of language instruction on the development of pragmatic competence needs to be studied more carefully. For Kasper, the conventional language classroom discourse does not provide the students with necessary opportunities, by means of which the non-native speakers are able to better communicate with the outside environment because the classic language format can neither provide the necessary instructional input nor lead toward productivity on the language user's end (1997: 9).

\section{Building Pragmatic Competence Through the Common European Framework of Reference for Languages (CEFR)}

At this point, it would be appropriate to concentrate on the ways that would help the development of language learners' pragmatic competence. In order to acquire sociopragmatic and pragmalinguistic information, the Common European Framework of Reference for Languages (CEFR) suggests a series of 
activities and precautions taken up in the form of awareness-raising initiatives. In this respect, CEFR defines plurilingual and pluricultural competence as, "the ability to use languages for the purposes of communication and to take part in intercultural interaction, where a person, viewed as a social agent has proficiency of varying degrees, in several languages and experience of several cultures. This is not seen as the superposition or juxtaposition of distinct competence, but rather as the existence of a complex or even composite competence on which the user may draw" (2001: 168). The CEFR suggests that language instruction should not only facilitate the achievement of linguistic forms, but also promote language instruction to function appropriately and fluently in various sociocultural contexts. To achieve this ultimate aim, the curricula proposed in CEFR are guided by three main principles: the first promotes plurilingualism and linguistic diversity; the second draws attention to the developmental priorities in each chosen language; and the third suggests that the considerations and measures related to curricula need to be approached according to their roles in language education and from a broader perspective, within which the language users' linguistic knowledge and skills are also adaptable to the context of other languages (2001: 169).

Additionally, the curricular suggestions of CEFR focus on the transferability of linguistic knowledge and skills to the environment of other languages, which indeed facilitates the development of a well-established pragmatic competence. It suggests that neither the language instructors nor the learners have the luxury to approach language learning only in itself - be it native, second or foreign. For CEFR, language learning should not occur separately from its other vital component, the knowledge of the world. The coverage of linguistic forms and functions should not only be considered within the limits of that language, but as a communicative tool which embodies sociopragmatic conventions for efficient and effective language production either in spoken or written format. Likewise, the characteristics of a particular European society and culture can be abridged in terms of everyday living, the living conditions, interpersonal relationships, the relation between power and solidarity, values, beliefs, and attitudes, body language, social conventions and ritual behaviors (2001: 101-104). The CEFR, in the light of scientific research that has been carried out to study linguistic, communicative and pragmatic competences, also focuses on the ways and strategies to develop each type of competence for communicative practices. It can be fairly said that the CEFR serves as a summary of the scientific findings that promote the development of a carefully designed curriculum to help language learners in becoming successful 'global communicators' by increasing their pragmatic awareness through well-designed activities and tasks. 


\section{Teacher's Role and the Approaches to be Applied in the Classroom to Raise EFL Students' Awareness of Pragmatic Competence}

Obviously, the teacher's role in raising EFL students' pragmatic awareness is quintessential. There are a number of challenges in teaching L2 pragmatics since the classroom environment does not offer a pragmatically relevant context either to the language teacher or the students. Therefore, teachers play a significant role in developing the students' pragmatic awareness and, in most cases, they become the only role model. In this respect, the focus has to be on what the language teacher knows first as regards the overall global knowledge. The second stage should be about what to do. Ishihara \& Cohen according to the table that follows, indicate what teachers should know to teach L2 pragmatics (2010: 189):

\begin{tabular}{|l|l|}
\hline $\begin{array}{l}\text { Selected components of teacher } \\
\text { knowledge for teaching L2 in general }\end{array}$ & $\begin{array}{l}\text { Components of teacher knowledge } \\
\text { specifically required for teaching of L2 } \\
\text { pragmatics }\end{array}$ \\
\hline Subject-matter knowledge & $\begin{array}{l}\text { Knowledge of pragmatic variation. } \\
\text { Knowledge of a range of pragmatic } \\
\text { norms } \\
\text { in the target language. } \\
\text { - Knowledge of meta-pragmatic } \\
\text { information }\end{array}$ \\
\hline Pedagogical-content knowledge & $\begin{array}{l}\text { (e.g., how to discuss pragmatics). } \\
\text { Knowledge of how to teach L2 } \\
\text { pragmatics. }\end{array}$ \\
\hline $\begin{array}{l}\text { Knowledge of how to assess L2 } \\
\text { pragmatic }\end{array}$ \\
curricular, and educational contexts \\
ability.
\end{tabular}

Table 2: The components required for the teaching of L2 pragmatics

As a whole, the types of knowledge that language teachers should possess are classified in terms of subject-matter knowledge, pedagogical-content knowledge and knowledge of the learners and local, curricular and educational contexts. By being aware of these components, teachers prepare the basis of intercultural competence for their learners. Moeller and Nugent state: 
"When intercultural competence is an integral part of the language classroom, learners experience how to appropriately use language to build relationships and understandings with members of other cultures. They can examine their own beliefs and practices through a different lens, negotiate points of view different from their own, and gain an insider's perspective of another culture" (2014: 14).

When this view is examined together with the table that precedes it, one can state that what teachers know has a great impact on what and how they approach language teaching, evaluation and curriculum development. Lenchuk and Ahmed add that ". . . the acquisition of pragmatic competence is facilitated by conscious attention to and critical awareness of the sociolinguistic and sociocultural variables that underlie the pragmatic behavior of native speakers" (2013: 85). In terms of the approaches in teaching pragmatics in foreign language contexts, Ishihara also refers to the benefits of deductive and inductive approaches. In the former, approach, the teacher plays a key role in introducing pragmatic discourse to students. The learners analyze samples and, with the teacher's guidance, discover pragmatic norms in the FL environment and become further enlightened about socio-cultural conventions and practices. On the other hand, again, according to Ishihara, inductive instruction is another option for teaching L2 pragmatics. This is a more learner-centered approach in which the teacher's input only helps self-discovery by students, of pragmatic norms (2010: 117-18).

It is quite worth mentioning at this point that the language teacher's own pragmatic knowledge, the methods and approaches for an appropriate and efficient pragmatic input might not be enough to achieve success in the formation of an intercultural competence. There are other challenges that need to be addressed accordingly. The text materials and the classroom climate are other factors to be dealt with. Still in many countries, teaching and learning a foreign language has not yet transcended its structural boundaries and traditional ways. There, language is isolated from its functional interpretation. Even, the functional representation and practice itself is structural, leaving no room for the development of communicative and pragmatic competences to frame intercultural competence. Yet, language is for communication, and it is not about memorizing structures to get higher grades in exams and, thereby, appeasing concerned faculty and parents come the end of the semester. Thus, the text materials and the classroom atmosphere are two crucial factors that have to be considered seriously; both should offer opportunities to the teachers and students to facilitate intercultural dialogue. The text materials should not only represent features of the target culture, but also those of the global community from which learners can obtain a variety of cultural inputs. In this way, the deductive role of the teacher minimizes and the selective attention of the students can range greatly through the various aspects of the global community. Once students begin to understand that learning a language is 
a tool for global communication, their interest towards becoming a member of the global community starts to grow. As Elosúa states, “. . . intercultural competence does not appear from one day to the next, rather, it is necessary to develop intercultural competence intentionally, this learning and development can happen through suitable preparation, meaningful intercultural interactions and the construction of authentic relationships" (2015: 75). In addition, as Erikson (1950) in his book 'Childhood and Society' claims, identity is at the heart of an individual's personal development and the term itself has both personal and collective implications. When Erikson's definition is considered, the two dimensions of the individual's identity appear to be complementary. That is to say, the development of a personal identity is not enough to be successful in interpersonal relationships, where socio-cultural conventions are logically and globally practiced. Briefly put, as Elosúa sums, “. . . intercultural competence is not an automatic phenomenon, it has to be directed through the different educational terms and institutions with a clear educational objective. Only in this way can we incorporate the process of development and optimization of intercultural competence as a core of our educational programmes. . " (2015: $80)$.

\section{Implications for Teaching Pragmatic Competence}

Linguistic theoretical input helps language learners to establish a strong background that would pave the way to sociocultural practices. However, such a background is not enough to practice language in differing discourses. There is a necessity for language learners to further their knowledge of intercultural competence. In this respect, pragmatic competence studies the human perception from a multi-dimensional view, in which linguistic knowledge and conventions are tied with the essentials of sociocultural communication in order to establish proper communicative practices as a product of knowledge and higher-order thinking skill. In such a communicative act, there are no breakdowns or pragmatic failures, but a comprehensive understanding between the addresser and the addressee. The studies in the language classroom to shape pragmatic competence, thus, set up the roots of an intercultural competence which enables the real practice of linguistic forms-functions, communicative strategies and pragmatic conventions in various contexts. Araja and Aizsila discuss the outcomes of raising EFL students' awareness of intercultural competence in the following items (2010: 223):

1. Foreign language and cultural studies are inseparable. Language cannot be taught without studying culture;

2. Acquiring intercultural communicative competence requires profound knowledge of one's own culture; 
3. Different culture studies enrich student's own perspectives;

4. Acquiring intercultural communicative competence demands new learning strategies; and

5. Intercultural communicative competence involves knowledge, skills and abilities for qualitative and adequate behavior in the target culture.

These five outcomes share the same center of attention with the CEFR since linguistic studies (structural, functional, pragmatic and semiotic) are framed with the conventions of intercultural competence. Atay et.al. add that "teacher education programs should include a cultural aspect in their curricula, such as a course on intercultural communication, in order to equip prospective teachers with intercultural awareness and intercultural competence ... once language teachers become more knowledgeable and competent regarding this issue, they will eventually be more able to integrate cultural practices in their teaching" (2009: 133). Here, it is important to note that the teacher's awareness about intercultural conventions is a fundamental factor in increasing students' intercultural communicative practices. Teachers are responsible for establishing proper intercultural curricula, thereby enabling the students to practice linguistic tools strategically and appropriately.

There are other practices that could facilitate the improvement of intercultural competence. Integrating literary and translation studies in EFL curriculum, and the use of multimedia-digital technology can also serve this purpose, to name a few.

As to translation studies in foreign-language teaching, the field has received a lot of attention from researchers, with the outcomes indicating that there is a close and statistically meaningful relationship between success in FLL and translation practices. For instance, even some ELT departments offer translation courses to their students in second or third grades in which the students are provided with the opportunity to become aware of intercultural practices since a wide range of morphology and syntax is deal with during the translation process. As Elorza mentions:

“... translation activities seem most appropriate for dealing with cultural issues in the classroom because they are easily approached as problem solving activities, where students must take decisions about the production of the translated text, thus raising questions related to cultural norms and requirements or merely to different ways of saying or doing things, as well as to the evaluative perceptions of the text from the target culture readers" (2008: 265).

Thus, translation activities introduced in language classrooms, too, can serve to develop the cognitive and meta-cognitive awareness of the language learners 
which in later terms not only advocates general critical thinking skills, but also promotes a target-oriented analytical understanding of discourse represented in different intercultural contexts.

Relatedly, literature studies (literature courses) offered in the ESL curriculum are another way to foster students' intercultural communicative competence. The results of a research on the relationship between literary studies in the FL classroom and establishing an intercultural competence indicate that:

“... learners become aware of the intercultural connections they were able to evaluate and criticize, and that these points of connection (gender roles in patriarchal societies, discrimination, prejudice, and conflicts between children and parents) allowed them to foster their critical intercultural competence in the language classroom" (Gomez Rodriguez 2014: 149).

Briefly, through selected readings in the EFL classroom, the students find the chance to experience ideas, issues and concerns related to sociocultural practices. Discussions, written exercises, assignments and related research help language learners to become competent and proficient users of a target language, in which they have developed an awareness of intercultural competence.

The use of multimedia (digital) technologies also contributes to the formation of intercultural competence in the EFL classroom According to Panturu, "the information technology and the multimedia means, had become meaningful resources for education, in general, especially for the intercultural education" (2010: 21). The educational context offered via multimedia enables language learners to practice a variety of skills and capabilities embodied in linguistic, communicative and pragmatic competences. The intercultural contexts, facilitated by mass-media, provide the students with the opportunity to become aware of different social practices in which L2 is used in its natural discourse. Desktop computers, tablet computers, cell phones, and other educational software developed to enrich students' socio-cultural competence have started to receive much attention from the $\mathrm{Y}$ and $\mathrm{Z}$ generations nowadays. In this respect, it can be said that the educational activities not only help students to create a basis to access various intercultural products in shorter periods of time, but also enable them to develop an intercultural linguistic behavior and attitudes.

\section{Conclusion}

Raising EFL students' awareness of pragmatic competence to structure an intercultural competence is perhaps one most important challenge, both for the language instructors and for the students. Though linguistic studies provide sufficient bases to inform teachers' and students' in developing sociocultural conventions for language production, still a series of strategies need to be deployed to achieve success. As Gomez Rodriguez states, "The EFL classroom should not 
only be a place to study grammar and language skills in a congratulatory way, but a place to promote critical interculturality through authentic language use" (2014: 149). There can be no doubt that the more learners of a foreign language develop their pragmatic abilities, the more successful communicators they become in the target language. Promoting a strong linguistic competence fosters communicative practices in the learner's communicative competence. Different aspects of verbal/non-verbal languages practiced in various discourses - even better if the context is enriched with semiotic input - help language learners to become proficient users in the target language. In this respect, pragmaticallyoriented social behavior which embodies political, sociocultural and economic conventions, should be integrated to the language curriculum via translation studies, literary studies and multimedia digital technology. Here, it is important to note that in a broader sense, the pedagogy of teaching linguistic skills and reflecting different aspects of linguistic competences need to be carefully designed in order to serve both the theoretical and practical (communicative) needs of the language learners either in written or oral formats. Briefly put, since cognitive and meta-cognitive skills are critically, creatively and strategically used and practiced, learners would start to become familiar with intercultural issues and matters. Through this process, they both develop their intercultural competence and form a better understanding of global issues as well as their own identities as members of that same global society.

\section{References:}

Abolfathiasl, Abdullah 2015: Abolfathiasl H., N. A. Abdullah. Pragmatic ConsciousnessRaising Activities and EFL Learners' Speech Act Performance of Making Suggestions. - Journal of Language Teaching \& Research. vol. 6(2), Mar. 2015, 333-342.

Araja, Aizsila 2010: Araja A., A. Aizsila. Intercultural Communicative Competence. Research for Rural Development. - International Scientific Conference. vol. 2, 220 224.

Atay et al. 2009: Atay D. T., Kurt G. T., Çamlıbel Z. T., Ersin P. T., Ö. T. Kaslıŏglu. The Role of Intercultural Competence in Foreign Language Teaching. - Inonu University Journal of the Faculty of Education (INUJFE). vol. 10(3), 123-135.

Bachman 1990: Bachman L. F. Fundamental Considerations in Language Testing. Oxford: Oxford University Press.

Bardovi-Harlig, Griffin 2005: Bardovi-Harlig K., R. Griffin. L2 Pragmatic awareness: Evidence from the ESL Classroom. - System. 33(3), 401-415.

Brown 2007: Brown D. H. Principles of Language Learning and Teaching. White Plains: Longman.

Canale, Swain 1980: Canale M., M. Swain. Theoretical Bases of Communicative Approaches to Second Language Teaching and Testing. - Applied Linguistics. I(1), $1-47$. 
Canale 1983: Canale M. From Communicative Competence to Communicative Language Pedagogy. - In: Richards J.C., R. W. Schmidt. (eds.). Language and Communication. 2-27.

Chomsky 1965: Chomsky N. Aspects of the Theory of Syntax. Massachusetts: M.I.T.

Choraih et al. 2016: Choraih M. A., Loutfi A., A. Mansoor. The Importance of Pragmatic Competence in the EFL Curriculum: Application and Implications. - Arab World English Journal. vol. 7(4), 183-195.

Common European Framework of Reference for Languages 2001: Common European Framework of Reference for Languages. Learning, Teaching, Assessment. Cambridge, U.K: Press Syndicate of the University of Cambridge.

Crystal 2008: Crystal D. Dictionary of Linguistics and Phonetics. Malden, MA: WileyBlackwell. Discovery eBooks. < http://www.mohamedrabeea.com/books/book1_3891. pdf $>$ [Accessed 21 Feb. 2017]

Elosúa 2015: Elosúa M. R. Intercultural Competence in the Education Process. - Journal of Education and Learning. vol. 4(1), 72-83.

Erikson 1950: Erikson E. H. Childhood and Society. New York: W. W. Norton.

Fodor, Garrett 1966: Fodor J. A., M. F. Garrett. Some Reflections on Competence and Performance. - In: Lyons J., R. J. Wales (eds.). Psycholinguistics Papers: The Proceedings of the 1966 Edinburgh Conference. Edinburgh: Edinburgh University Press.

Fukuya, Martyn 2001: Fukuya Y. J., K. C. Martyn. A Comparison of Input Enhancement and Explicit Instruction of Mitigators. University of Hawai'i at Manoa < http://files.eric. ed.gov/fulltext/ED503649.pdf> [Accessed 2 Apr. 2017]

Gómez Rodríguez 2014: Gómez Rodríguez L. Relational Teaching: A Way to Foster EFL Learners' Intercultural Communicative Competence through Literary Short Stories (Research). ["Enseñanza relacional: una forma de desarrollar la competencia comunicativa intercultural de estudiantes de inglés como lengua extranjera a través de cuentos literario"]. - Colombian Applied Linguistics Journal. vol. 16(2), 135-150.

Gumperz, Dell 1989: Gumperz J. J., H. H. Dell. Directions in Sociolinguistics: The Ethnography of Communication. Oxford: Basil Blackwell.

Hymes 1972: Hymes D. H. On Communicative Competence. - In: Holmes J., J. B. Pride (eds.). Sociolinguistics: Selected Readings. Baltimore: Penguin Books Ltd, 269-293.

Ishihara, Cohen 2010: Ishihara N., A. D. Cohen Teaching and Learning Pragmatics: Where Culture and Language Meet. Harlow: Pearson Education.

Kasper 1997: Kasper G. Can Pragmatic Competence be Taught? (Network\#6). - Honolulu: University of Hawai'i, Second Language Teaching \& Curriculum Center. < http://www. nflrc.hawaii.edu/NetWorks/NW06> [Accessed 28 March 2017]

Kasper, Rose 2002: Kasper G., K. R. Rose. Pragmatic Development in a Second Language. Language Learning: A Journal of Research in Language Studies, vol. 52, Language Learning: A Journal of Research in Language Studies. EBSCOhost, <search.ebscohost. com/login.aspx ?direct $=$ true $\& d b=$ eric $\& A N=E D 476838 \&$ site $=$ ehost-live. $>$ [Accessed 2 Apr. 2017]

Krisnawati 2011: Krisnawati E. Pragmatic Competence in the Spoken English Classroom. - Indonesian Journal of Applied Linguistics. 1(1), 105-115.

Leech 1983: Leech G. N. Principles of Pragmatics. London: Longman. 
Lenchuk, Ahmed 2013: Lenchuk I., A. Ahmed. Teaching Pragmatic Competence: A Journey from Teaching Cultural Facts to Teaching Cultural Awareness. - TESL Canada Journal, vol. 30(7), Special Issue, 82-97.

Mey 1993: Mey L. Jacob Pragmatics: An Introduction. Oxford: Blackwell.

Moeller, Nugent 2014: Moeller A. K., K. Nugent. Building Intercultural Competence in the Language Classroom. - University of Nebraska-Lincoln, Faculty Publications: Department of Teaching, Learning and Teacher Education. $<$ http://digitalcommons.unl. edu/cgi/viewcontent.cgi?article $=1160 \&$ context $=$ teachlearnfacpub $>$ [Accessed $16 \mathrm{March}$ 2017]

Mwinyelle 2005: Mwinyelle J. B. The Acquisition of Pragmatic Competence in an L2 Classroom: Giving Advice in Spanish. Diss. University of Texas at Austin. https://repositories.lib.utexas.edu/bitstream/handle/2152/2009/mwinyellej65109. pdf? sequence $=2 \&$ isAllowed $=\mathrm{y}>$ [Accessed 1 Apr. 2017]

Oller Jr. 1970: Oller Jr., J. W. Transformational Theory and Pragmatics. - Modern Language Journal 54(7), 504. Publisher Provided Full Text Searching File. < http:// www.jstor.org/stable/321771> [Accessed 21 Feb. 2017]

Panturu 2010: Panţuru S. The Informative - Formative Valences of Multimedia Technologies in the Intercultural Education Framework. ["Valenţele informativformative ale tehnologiei multimedia în educaţia interculturală"]. - Petroleum - Gas University of Ploiesti Bulletin, Educational Sciences Series, vol. 62(1)A, 19-24.

Li et al. 2015: Li R., Raja R., A. Sazalie. The Relationship between Motivation and Pragmatic Awareness: A Case Study of Chinese EFL Learners. - 3L: Southeast Asian Journal of English Language Studies, vol. 21(3), 41-55.

Van Dijk 1977: Van Dijk T. A. Context and Cognition: Knowledge Frames and Speech Act Comprehension. - Journal of Pragmatics. 1(3), 211-231.

Wales, Marshall 1966: Wales R. J., J. Marshall Psycholinguistics Papers. In: Lyons J., R. J. Wales (eds.). Psycholinguistics Papers: The Proceedings of the 1966 Edinburgh Conference. Edinburgh: Edinburgh University Press.

Widdowson 1963: Widdowson H. G. Learning Purpose and Language Use. Oxford: Oxford University Press. 